\title{
An Assessment Of Trade Openness On Gender Inequality: An ARDL To Co-Integration Approach (A Case Study Of Pakistan)
}

\author{
Nooreen Mujaheed \\ \& \\ Azeema Begum \\ Department of Economics \\ University of Karachi
}

\begin{abstract}
The impacts of trade policies are ambiguous for male and females due to difference in social status, economic opportunity and control over resources in developing countries. Unfortunately, trade policies are gender blind and overlook female's concern and objectives. It is fact that trade openness promotes economic development but it is still unclear its impact on females. The study investigates the impact of trade openness on gender inequality in case of Pakistan from the period of 1985 to 2015. We have taken gender inequality index generated by Ahmed and Bukhari (2007), foreign direct investment, trade openness, Female labour force participation, enrolment ratio of females, and government spending on health and education sector. After applying Autoregressive Distributed Lag Model (ARDL) to co-integration and Vector Error Correction Estimation (VECM) technique, the results demonstrate the sign of stationary of time series variables, and short run as well as of long-run equilibrium relation among variables. However, trade liberalization polices will be beneficial if its help to increase the export sector. Export sectors of Pakistan are on textile, clothing and mostly on agriculture products where mostly female are employed. Increasing share of government spending in health and education will indirectly affect the women health ability in order to enhance their social status and access over the economic recourses which can reduce the gender inequality in Pakistan.
\end{abstract}

Keywords: Gender Inequality, Trade Liberalization, Foreign Direct Investment, Government Expenditures.

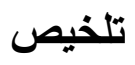

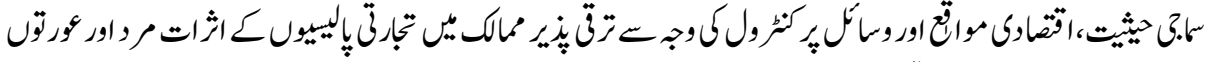

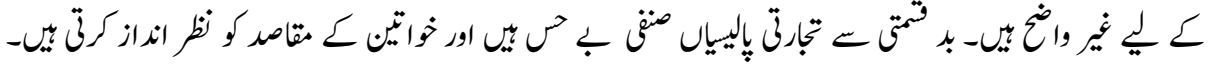

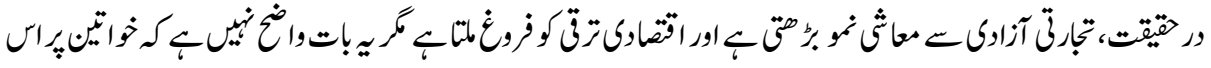

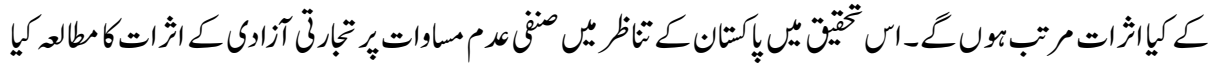

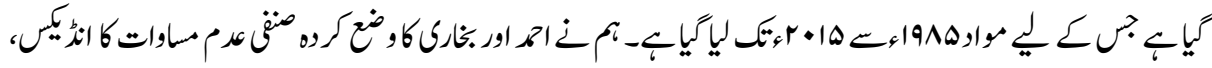

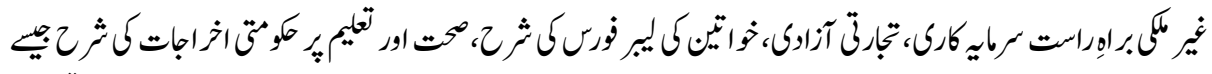

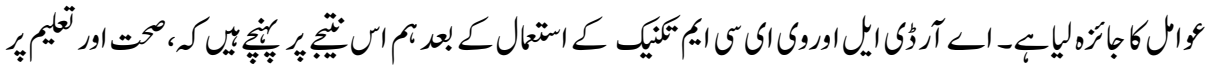




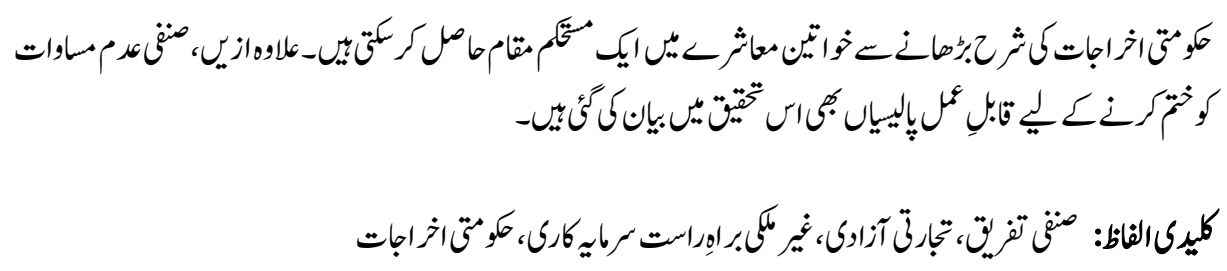

\section{Introduction}

Over last two decades mostly economies are opening their markets and liberalize their economy through free trade agreement, investment, de- regularization of the private sector and financial market, and privatization of the state owned organizations and achieve the higher level of growth and productivity. It expands the employment opportunities in order to maintain living standard for both gender and also provides the equal opportunities to get the benefit from trade liberalization policies however, trade policy is recognized as gender neutral.

The impacts of trade policies are different for male and females in the economic activities due to difference in social status, access and control over the economic recourses. Unfortunately gender issues are not being considered after economic, social and cultural development and there is no any country who tried to take steps to eradicate the gender gap from societies (Saadia \& Augusto, 2005). It is also surprising that the studies and research on trade and gender are comparatively new (Senapaty, 2003).

Although gender discrimination or gender inequality is very complex subject to study however, feminist theories have explained the position of women in labour market which reflects patriarchy and subordinate position of the women in society as well as in their family. (Anker, 1998). Moreover feminist argues that jobs which are classified as female occupation get lower wages than men occupations which is certainly based on sex discrimination rather than productivity and reflection of cultural discrimination against female's worker. There is a direct negative effect between women right and trade policies and most of the time trade rules and policies damage the women rights (Mengesha, 2006). It is a fact that trade openness promotes economic development but its impact on women is still unclear.

Trade liberalization had improved empowerment of women and their livelihoods (Nordas, 2003) however overall benefits which acquired by men from trade liberalization is more than women (Mcgill, 2004) trade liberalization has made gender inequality worse and demoralized the status of the women (Margawati, 2007). Feminist economist Hoskyns (2006) and Seguino (2006) explain that gender issues should be an essential part of macroeconomics variables and economic development and economic growth could be effected by gender relation. Mostly development economist investigated the relationship between trade and gender such as. Korinek (2005)found that trade openness give employment opportunities to 
female in developing countries however, it is still questionable that women's share in paid employment will increase in export sector of the country especially.

Gender inequality can be studied through different perspective distribution of labour in term of paid and unpaid work, division of economic resources and employment separation in labour market, access to public services such as health and education and representation of women in the policy making. However trade policies were silent regarding gender aspect of employment and did not illustrate their implication on women, because the main purpose of trade liberalization was to increase the export and bring export -led growth in the economy, which could increase employment opportunity for both men and women and competition. However, in this whole process of trade liberalization the socio-cultural realities, problems and constraints on women economic activities had not considered.

Rest of the paper is designed as section 1 is introduction; Section 2 provides the review of literature. Data and methodology are given in section 3. Section 4 shows result and discussion. Finally Section four concludes discussion and provides policy implication.

\section{Review of Literature}

There are numerous studies which examine the effect of trade liberalization policies on employment of women and gender difference. Joseph (2014) provided the empirical and theoretical evidence on the relationship between trade liberalization and the informal economy. He studied that how the relation changes between men and women who are working in the informal economy. Existing theoretical evidence proves that trade liberalization did not yield gender neutral outcomes. It influences men and women extraordinarily due to disparities in labour market opportunities, which were related to their earnings and employment.

Shireen Alazzaw (2014), investigated the linkage between women's labour market supply in the industry and manufacturing sector, the measure of manufacturing concentration and the trade policies regarding reforms always took place simultaneously. Results indicate that industry concentration is negative to women in the labour market. Furthermore, the impacts of trade liberalization vary depending on the level of absorption of female labour supply and the international competition. At initial level competitive industries always try to increase imports for setup new industries, consequently that increase imports were related higher gender wage gaps and lower female employment in Egypt. Chinhui Juhn et al. (2013) analyzed the underexplored area of gender inequality due to trade liberalization by using the establishment level data of Mexico. They tried to find the impact of reduction in tariff on female wage bill shares in blue-collar jobs. A decline in tariffs encourages domestic firms to update their technologies in order to enter in export market. New technologies require less physical skills so women employment and wages can increase in blue collar jobs however, there is less opportunities for females in white collar tasks.

Irene Musselli et al. (2012) evaluated the relationship between trade gender inequality and development of three different countries by using various methodologies. In the case 
study of Cape Verde, he used micro data to examine the distributive consequences of trade policies on households especially on women. In second method they collectively used both qualitative and quantitative methodologies. The case study of Lesotho was based on interconnections of structural changes in the economy and trade policies and then shifting of female employment. In the case study of Gambia, they had emphasized on qualitative methods of investigation, with the aims to find out the role of women in export-oriented sectors specifically, for instance the fishery sector of Gambia, they found that commitments regarding gender equality and economic empowerment of women, and trade policy instruments are disconnected. Although every country has made commitments to increase gender equality at national level, however gender issues mostly disappear when other macroeconomic policies are designed and implemented along with trade agreement are negotiated.

Rashmi (2012) studied female access over health and education as the sign of gender inequality and analysed the gender inequality situation at state level. Further, the results indicate that at the sub-national level there is low level of gender inequality with some high level per capita income in few states. However, gender inequality was also very high in several high income states. High level of gender inequality was also detected in some states which attain high rank in the openness index. Asma Hyder et al. (2011) examined female and male labour force participation trends by using five census reports and the two Labour Force Survey reports for 57 years of Pakistan. They examined the impact of trade liberalization on labour force participation rates of male and females in wide occupational groups in Pakistan. They concluded that the gender gap has decreased as trade openness increased between male and female. The demand of female labour also encouraged due to changes in production composition of GDP. Rashmi (2010) examined that trade is actually substitute for free market, and as a result gender inequality and poverty of women can be effectively reduced in developing countries. First, he analyzed neoclassical theories and trade liberalization policies then observed the role of trade in correcting market; thereby trade make free markets more efficient in distribution of resources. Then he identified the gendered composition of free trade and tackled the main issues related to trade liberalization and women in LDCs. He revealed that free trade can reduce gender inequality within global capitalist structures but it requires more empirical investigation.

Alexander et al. (2010) studied the impact of trade openness on female employment in manufacturing sector particularly, of 60 developed countries with high level of income and developing countries with middle income level from the period of 1985 to 2007. They found that relative employment of female decreased in developed countries but increased in developing countries. Zahra karimi, (2008) conducted an informal survey in the Iranian city of Kashan for investigating the impact of international competition on carpet weavers. Trade competition reduced the real wages of weavers and changed the labour force structure of the industries. He analyzed that the middle income people who belonged to this industry are leaving and poor Afgan migrants are taking their places. Moreover, in household level women are working as subordinate in weaving as employment, although economic globalization has improved Iran's exports related to energy extensively, however major labour-intensive exports, particularly hand-made carpets, declined in last twenty year. The 
results of survey illustrated that as an employment, carpet weaving is a sign of poverty which has very low earning than formal minimum average. Consequently now mostly women were not interested any more in carpet weaving industry, however low income families still relay on the carpet weaving. Naeem Ahmed et al. (2007) focused on gender inequalities due to liberalization of trade in case of Pakistan by using data from 1973 to 2005 . They have taken per capita GDP, GDP ratio of import and export, ratio of number of girls school to number of boys school for determining of overall gender inequality in Pakistan. The regression results demonstrate a significant association of trade liberalization on over all gender inequality, particularly in the labour market of Pakistan. Rizwana Siddique (2007) analysed the gender dimension of impact of economic reforms using poverty indicators, trade liberalization policies and cut in government expenditures and explained that both policies hurt women as compared to men in Pakistan. In trade liberalization exercise she found that trade liberalization policies increases poverty to women among poor household and decreases in rich household relative to men. She suggested that education is most important variable which can help to reduce the poverty of women, wage income and time allocation and capabilities. Matthias Busseet, al (2006) explored the global association of gender and trade by taking sample of 92 developed and developing countries. They focused on the study of comparative advantage in manufacturing goods but labor-intensive in nature. The results demonstrate that inequality in term of gender wage was directly associated with comparative advantage in labour-intensive goods, especially those countries which exports larger amount of these goods with huge gender wage gap. Moreover, other dimension of gender inequality such as educational attainment rates and labour force activity rates were inversely linked with comparative advantage in labour-intensive goods.

Pradhan (2006) found a positive relation between female employment and trade by analyzing Indian industry and plant-level data, and also found negative relationship between foreign technologies movement and female employment, and no link between Foreign Direct Investment and female employment.

Berik et al. (2002) investigated the impact of global competition due to openness in labourintensive industries in both Taiwan and Korea. He found that wage gaps between men and women stretched during 1981 to 1999. Further strong regression results are for Taiwan which showed that rising import shares are directly related to increasing wage discrimination. Especially, this discrimination was registered in industries such as textile and electronic industries, where women are employed. However in case of Korea, a minor decline in export industries was uncertainly related to wage discrimination in industries against female 'workers of these industries. Kucera (2001) studied the effects of trade liberalization on gender relative wages and employment using data from 1970 to 1996 for Germany and Japan. He pointed out that supply of female labour was identical between these two countries and but those industries where female workers are employed are characterized as "trade losers" in both countries. He found that impact of trade expansion was negative for women of manufacturing sectors in Japan but not in Germany, because of different trading partners. Japan was trading with non-developed countries. However, Germany was involved in trade with non-OECD countries intensively. Wood (1991) and Sanding (1999) have analyzed the impact of increase export and female employment in 
export sector(manufacturing) during 1960-1985 and mid 1990s through cross sectional data of developed and developing countries and found a strong relationship between increase in employment of women in formal sector and increase in export.

Gender and development theory explained that impact of neoliberal trade policies and reforms is negative on women because of less access and control over economic resources for instance basic education, health facilities, training and skilled development and promotion in work places.

\section{Methodology and Modelling Frame Work}

On the basis of theoretical and empirical studies, we employ composite Gender Inequality Index, trade openness, Foreign Direct Investment, Public spending on health sector and education, female labour force participation, unemployment rate and primary and secondary enrolment rate of female. The functional form of model is portrayed as following:

$$
\text { GIIt }=\mathrm{f}(\mathrm{TOPt}, \text { FDIt, PSEt, PSHt, \%FLFPIt, \%UNEMt, ENRLt) }
$$

Where,

$\mathrm{GII}=$ Gender Inequality Index

$\mathrm{FDI}=$ Foreign Direct Investment (\% of GDP)

$\mathrm{PSE}=$ Public Spending on Education (\% of GDP)

$\mathrm{PSH}=$ Public Spending on Health (\%of GDP)

$\mathrm{FLFP}=$ Female Labour Force Participate rate

UMEM= Unemployment Rate

$E N R L=$ Primary and Secondary Female enrolment Rate

GII gender inequality index which measure is gender discrimination among women and men in labour market health and education generated by Ahmed and Bukhari (2007), TOP is trade openness which has been calculated by (import+export)/gdp, FDI is foreign direct investment \% of GDP, PSE and PSH are government expenditure on health and education as \% of GDP, UNEM is overall unemployment rate and ENRL is primary and secondary rate of females.

$\mathrm{t}=1,2,3 \ldots \mathrm{n}($ time period from $1985-2015)$

For experiential purpose, all variables have been converted in to econometric model. This specification of model provides efficient and consistent results without any biasness. The empirical equation is modelled

$(\text { GII })_{t}=\alpha_{0}+\beta_{1}(\text { TOP })_{t}+\beta_{2}(\text { FDI })_{t}+\beta_{3}(\% \text { PHE })_{t}+\beta_{4}(\text { PHS })_{t}+\beta_{5}$ L(FLFP)t + $\beta_{6}(\mathrm{UNEM})_{\mathbf{t}+} \boldsymbol{\beta}+\boldsymbol{\beta}_{7}(\mathrm{ENRL})_{\mathbf{t}}+\mathbf{e}_{\mathbf{t} . \ldots . .(2)}$

Where $=\alpha_{0}$ is intercept and $\beta_{1}, \beta_{2}, \beta_{3} \beta_{4} \beta_{5} \beta_{6} \beta_{7}$ are the coefficient of variables $\mathbf{e}_{\mathbf{t}}$ is residual term. 


\section{(a) Data Source}

In this study the time series data has been employed for the period 1985 to 2013 . The data is taken from UNCTAD, global economy, World Bank Indicators, and Pakistan bureau of statistics, various publication of economic survey of Pakistan, Statistical Year Book of Pakistan 2010, and labour force survey. Study will estimate the relationship between GII and trade openness as well as nexus among the explanatory variables

\section{(b) Methodology}

Time series data from the period of 1985 to 2013 is being used in this study, and it is very necessary to investigate the stationary in the data. Because without investigating the stationary, the result will be spurious. Stationary in the data is investigated by using various number of unit root tests. In this study ADF by Dickey and Fuller (1979) and PP by Philiph- Perron (1987) have been used to check the stationarity in the data.

In the next step we have used ARDL to integration approaches to test the relation between core variables. Wide range of empirical researches is available, where researchers have applied Ordinary least squared (OLS) method to examine the association among macroeconomic series. The main obscurity with OLS method is that it is already assumed that residual term is normally distributed with zero mean and finite constant. Without investigating the stationary by using unit root test of the variables, Ordinary Least Square gives ambiguous empirical result which may be not helpful for policy analysis. Secondly, it is required to test the integrating order of the series while investigating co integration relationship between the variables. If time series data are integrated at level 1 then Johansson Co integration test can applied however, the situation is more complicated. Because some time series data are integrated al level and some at $1^{\text {st }}$ difference of unit root test. That's why ARDL to Co-integration Approaches (Pesaran and Shin (1999) and (2001) provide appropriate results. However, before applying ARDL, make sure that no any time series should be integrated at $2^{\text {nd }}$ difference of unit root test.

The unrestricted error correction model (UECM) of autoregressive distributive lag modelling (ARDL) to Co-integration Approach is modelled as follows:

$$
\begin{aligned}
& \Delta \ln G I I_{t}=\vartheta_{1}+\vartheta_{2} T+\vartheta_{3} T O P_{t-1}+\vartheta_{4} F D I_{t-1}+\vartheta_{5} P S E_{t-1}+\vartheta_{6} P H S_{t-1}
\end{aligned}
$$

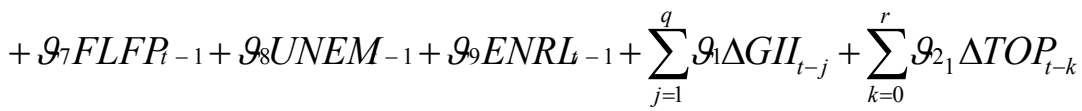

$$
\begin{aligned}
& +\sum_{l=0}^{s} \vartheta_{3} \Delta \ln F D I_{t-i}+\sum_{m=0}^{t} \vartheta_{4} \Delta \ln P E S_{t-m}+\sum_{n=0}^{u} \vartheta_{5} \Delta \ln P H S_{t-n}+\sum_{o-0}^{v} \vartheta_{6} \Delta F L F P_{-o}
\end{aligned}
$$

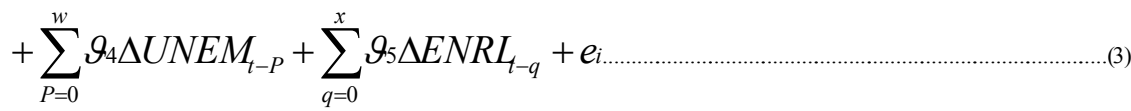


The null hypothesis of no co-integration is

$H o: \vartheta \mathrm{GiI} I=\vartheta \mathrm{TOP}=\vartheta \mathrm{FDI}=\vartheta \mathrm{PSE}=\vartheta \mathrm{PHS}=\vartheta \mathrm{FLFP}=\vartheta \mathrm{UNEM}=\vartheta \mathrm{ENRL}=0$

And hypothesis of co-integration is

$H_{1}: \vartheta G I I \quad I \neq \vartheta T O P \quad \neq \vartheta F D I \neq \vartheta P S E \quad \neq \vartheta P H S \neq \vartheta F L F P \neq \vartheta$ UNEM $\neq \vartheta$ ENRL $\neq 0$

Although the diagnostic tests have also been conducted to test the problem of normality, serial correlation, conditional heteroskedasticity, and specification of the model after testing the ARDL to co integration testing model.

Once long run relationship between variables is established, it is necessary to find short run impact of trade openness on gender inequality in case of Pakistan. In doing so, we have applied Error Correction Method (ECM). The ECM is modelled as follows

$$
\begin{aligned}
\Delta G I I_{t}= & \delta_{\circ 1}+\sum_{i=1}^{l} \delta_{1} \Delta G I I_{t-i}+\sum_{j=0}^{m} \delta_{2} \Delta T O P_{t-j}+\sum_{k=0}^{n} \delta_{3} \Delta F D I_{t-k}+\sum_{l=0}^{o} \delta_{4} \Delta P S E_{t-l} \\
& +\sum_{m=0}^{p} \delta_{5} \Delta \ln P S H_{t-m}+\sum_{n=o}^{q} \vartheta_{6} \Delta F L F P_{t-n}+\sum_{o=0}^{r} \vartheta_{7} \Delta U N E M_{-o}+\sum_{o=0}^{r} \vartheta_{8} \Delta E N R L-P+\vartheta E C M_{t-1}+\varepsilon_{i} . .
\end{aligned}
$$

Where $t-1 E C M$ is lagged error term. It is the estimate of lagged error term which capture the speed of adjustment from short run towards long run equilibrium.

\section{Results and Discussions}

Table: 1

Statistical descriptive

\begin{tabular}{|l|c|c|c|c|c|c|c|c|}
\hline & ENRL & FDI & TOP & GII & PSE & PSH & UNEM & FLFP \\
\hline Mean & 71.53310 & 1.064828 & 10.03595 & 131.4481 & 2.445862 & 0.721379 & 5.248276 & 16.08276 \\
\hline Median & 72.19000 & 0.690000 & 7.284274 & 132.0400 & 2.560000 & 0.720000 & 5.100000 & 15.10000 \\
\hline Maximum & 78.40000 & 3.670000 & 36.48515 & 142.4700 & 3.100000 & 1.190000 & 7.800000 & 24.46000 \\
\hline Minimum & 64.59000 & 0.330000 & 4.111262 & 122.0416 & 1.720000 & 0.470000 & 2.600000 & 8.600000 \\
\hline Std. Dev. & 3.8225876 & 0.876636 & 7.104520 & 6.136333 & 0.365166 & 0.197153 & 1.512477 & 4.620997 \\
\hline Skewness & -0.206823 & 1.843051 & 2.172679 & 0.135091 & -0.254553 & 0.805214 & -0.078744 & 0.438637 \\
\hline Kurtosis & 1.960532 & 5.438346 & 7.891086 & 1.673049 & 2.266788 & 2.779850 & 2.313307 & 2.264913 \\
\hline JarqueBera & 1.512345 & 23.60222 & 51.72254 & 2.215838 & 0.962785 & 3.192349 & 0.599756 & 1.582870 \\
\hline Probability & 0.469460 & 0.000007 & 0.000000 & 0.330245 & 0.617922 & 0.202670 & 0.740909 & 0.453194 \\
\hline
\end{tabular}

Source: Estimated and tabulated by Authors

The descriptive statistics are explained in table no. 1. The outcomes depict that all the series have homoscedastic variance and normal distribution as indicated by JarqueBera statistics where the mean values of, FDI, TOP, UNEM,PSH and FLFP are more than median values which indicates tendency toward positive skew whereas the mean value of ENRL, PSE, and GII are less than median value which shows negative skew. 
(a) Unit Root Test

Table: 2

ADF unit root test with trend and intercept

\begin{tabular}{|l|c|c|c|c|}
\hline \multirow{2}{*}{ ENRL } & \multicolumn{2}{|c|}{ Level } & \multicolumn{2}{c|}{ st $^{\text {st }}$ Difference } \\
\cline { 2 - 5 } & T-Statistics & Prob- values & T -Statistics & Prob- values \\
\hline FDI & -2.045644 & 0.5521 & -5.819180 & 0.0003 \\
\hline FLFP & -5.070917 & 0.0027 & -4.207654 & 0.0168 \\
\hline GII & -2.115267 & 0.5155 & -5.984726 & 0.0002 \\
\hline PSE & -3.384740 & 0.0738 & -6.545732 & 0.0001 \\
\hline PSH & -3.890144 & 0.0280 & -4.389409 & 0.0093 \\
\hline TOP & -3.248545 & 0.0958 & -3.701881 & 0.0396 \\
\hline UNEM & -4.492504 & 0.0068 & -5.841805 & 0.0004 \\
\hline
\end{tabular}

Source: Estimated and tabulated by Authors Critical Values at 1\%, 5\% and $10 \%$ level

The Augmented Dickey-Fuller (ADF) unit roots test is used to check stationary in time series data. Table 2 describes the unit root test of all variable at level and $1^{\text {st }}$ difference with trend and intercepts. At level, the values of ENRL, FLFP AND UNEM are insignificant however remaining variables are significant at $1 \%, 5 \%$ and $10 \%$ level. After taking unit root test at $1^{\text {st }}$ difference, the probability values show that all variables are without trends with less than $5 \%$ level. It is proved that all variables are integrated at I(1) which is confirmed by ADF test.

Table: 3

Philips Perron test with trend and intercepts

\begin{tabular}{|l|c|c|c|c|}
\hline \multirow{2}{*}{} & \multicolumn{2}{|c|}{ Level } & \multicolumn{2}{c|}{$\mathbf{1}^{\text {st }}$ Difference } \\
\cline { 2 - 5 } & T-Statistics & Prob- values & T-Statistics & Prob- values \\
\hline FDI & -1.846599 & 0.6547 & -7.822290 & 0.0000 \\
\hline FLFP & -1.441809 & 0.8253 & -3.411259 & 0.0708 \\
\hline GII & -2.085616 & 0.5311 & -8.328188 & 0.0000 \\
\hline PSE & -3.341208 & 0.0803 & -14.31472 & 0.0000 \\
\hline PSH & -2.394426 & 0.3742 & -3.295648 & 0.0884 \\
\hline TOP & -3.364908 & 0.0767 & -3.699883 & 0.0398 \\
\hline UNEM & -4.426943 & 0.0079 & -22.26250 & 0.0000 \\
\hline
\end{tabular}

Source: Estimated and tabulated by Authors Critical values at $1 \% 5 \%$ and $10 \%$ level

PP test is also used to check the trends in time series data. Table 3 shows the unit root test of all variable at level and $1^{\text {st }}$ difference with trend and intercepts. At level, the values of GII, PSH and TOP are significant at less than $10 \%$ critical value. However remaining variables are insignificant at level. After taking unit root test at $1^{\text {st }}$ difference, the probability values of ENRL, GII and TOP are significant at $1 \%$.The values of UNEM and PSH are significant at $5 \%$ level, and remaining variables are significant at $10 \%$ critical values. It is proved that all variables are integrated at I(1) which is confirmed by Philips Perron test. 
Now ARDL approaches of Co integration is being applied to determine the long and short run relationships. It has been already mentioned that the main assumption of ARDL is all variables should be co-integrated to the order of I(0) OR I(1) or both. In the first step, we have selected the lag length criteria on the basis of Akaike Information Criterion [AIC]).Because the computation of $\mathrm{F}$ statistic for Co-integration is sensitive to the lag length. After selecting the lag length we obtained ARDL model of Co-integration. The empirical outcomes of the ARDL model IS obtained by normalizing the gender inequality index are presented in Table-4(ARDL $(0,1,2,1,2,2,2,1)$ selected based on the AIC and long run relation on Table-5 (ARDL(0,1,2,1,2,2,2,1 and short run relationship in Table 6 (ARDL $(0,1,2,1,2,2,2,1)$ selected based on the Akaike Information Criterion [AIC]).

Table: 4

Estimated long run coefficients using the ARDL approach

\begin{tabular}{|l|c|c|c|}
\hline \multicolumn{5}{|c|}{ ARDL(0,1,2,1,2,2,2,1) selected based on Akaike Information Criterion } \\
Dependent variable is GII
\end{tabular}

Source: Estimated and tabulated by Authors

Table 4 demonstrates the ARDL model of integration which explains that the entire chosen variables have a long-term association with F-stat. 207.0670 and p-value 0.000. The significant values of trade liberalization and Foreign Direct Investment shows the significant relation with GII. However at first lag of FDI there is positive sign which shows positive association with GII but in second lag the coefficient sing turn again negative. The results 
support the theory that increase in trade will help unskilled labour of developing countries which are mostly females. Trade openness will bring more opportunities for female not only in labour market but also in health and education sectors.

The unemployment rate has negative and significant relation with gender inequality which is opposite in our study. The reason is that female has less ratio as compared to man in total labour force. If unemployment decrease which allow opportunities for male due to physical and mental strengthen. So he gap between male and female labour force increases more in labour market indirectly increases gender inequality. Female labour force participation have no relation in current year and in second lag due to insignificant values however the results support that increase in female labour force participation could help in decreasing gender inequality in first lag. Increase in female labour force participation will decrease the female gap in employment. Mostly female of rural areas are engaged in agriculture sector and urban women are engaged in textile and garment industries, fortunately these are main exports of Pakistan. Increase in exports of primary agriculture and textile goods, will be beneficial for women to get more jobs with less skill and knowledge. More chance of employment will help women to access the other necessities of life and it will improve their economic power along with the ability to take part in decision making for their own interest and benefits. This will indirectly decrease the gender inequality of female and improve human development level among female public spending on health have no link with gender inequality in current and first lag however in second lag there is negative and significant relation which shows that increase in government spending on heath will improve females health facilities in order to take more part in economic activities which will help to reduce gender inequality. Public spending on education has no relation in current lag. Female enrolment in primary and secondary education have negative and significant link with gender inequality, which proves that more enrolment in education by female will provide more opportunities in order to make them more skilled and improve their status in the society through more chance of getting jobs and employments. Increase in health and education expenditure by government will indirectly improve the health and skill of the women and they can take part in economic activities more actively. More access to health and education will improve human development level of women which indirectly decrease the gender inequality gap in these two areas.

Table: 5

Estimated long run coefficients using the ARDL approach ARDL(0,1,2,1,2,2,2,1) selected based on Akaike Information Criterion Dependent variable is GII

\begin{tabular}{|l|c|c|c|}
\hline Regressor & Coefficient & Standard Error & T-Ratio[Prob] \\
\hline TOP & -.16251 & .052593 & $-3.0900[.018]$ \\
\hline FDI & -1.0673 & .34762 & $-3.0702[.018]$ \\
\hline UNEM & -1.7872 & .43220 & $-4.1351[.004]$ \\
\hline FLFP & .15999 & .30604 & $.52277[.617]$ \\
\hline PSH & -11.7933 & 3.9223 & $-3.0067[.020]$ \\
\hline PSE & 5.6626 & 1.3497 & $4.1954[.004]$ \\
\hline ENRL & -.74666 & .24698 & $-3.0232[.019]$ \\
\hline C & 197.4640 & 17.1839 & $11.4912[.000]$ \\
\hline T & -.61209 & .12388 & $-4.9411[.002]$ \\
\hline
\end{tabular}

Source: Estimated and tabulated by Author 
The table :5 above demonstrates the estimated long-term coefficients using an ARDL approach to co integration, which illustrates that GII have much influence on Trade openness in the long run.. Furthermore, GII have long term association with all selected variables in the model at $1 \%$ and 5\% level of significance However, there is no association between gender inequality and female labour force participation rate $\%$.

Table: 6

Error correction model for short run

\begin{tabular}{|l|c|c|c|c|}
\hline \multicolumn{5}{|c|}{ Dependent Variable: D(GII) } \\
\hline Variable & Coefficient & Std. Error & t-Statistic & Prob. \\
\hline C & -0.440398 & 0.191531 & -2.299364 & 0.0330 \\
\hline D(TOP) & 0.032869 & 0.083332 & 0.394428 & 0.6977 \\
\hline D(FDI) & 0.034833 & 0.059941 & 0.581115 & 0.5680 \\
\hline D(ENRL) & -0.005047 & 0.038267 & -0.131890 & 0.8965 \\
\hline D(FLFP) & -0.554662 & 0.156115 & -3.552910 & 0.0021 \\
\hline D(PSE) & -0.333707 & 0.664364 & -0.502295 & 0.6212 \\
\hline D(PSH) & -2.107665 & 1.547086 & -1.362345 & 0.1890 \\
\hline D(UNF) & -0.390461 & 0.205603 & -1.899106 & 0.0728 \\
\hline ECM(-1) & -0.822990 & 0.141752 & -5.805826 & 0.0000 \\
\hline R-squared & 0.701939 & Mean dependent var & & -0.716636 \\
\hline Schwarz criterion & 2.947657 & Akaike info criterion & & 2.519448 \\
\hline F-statistic & 5.593180 & Durbin-Watson stat & & 1.896678 \\
\hline Prob(F-statistic) & 0.000997 & & & \\
\hline Source: Estimated & & &
\end{tabular}

Source: Estimated and tabulated by Author

Table 6 represents short run association among the variables. For short run two criteria should be fulfilled that ECM value should be negative and significant. In the short-term analysis, The extent of coefficient of ECT depicts that the speed of variation from short run to the long run path. The coefficient value of ECM (-1) is -0.822 which is negative and highly significant, illustrates the high rate of adjustment from short run equilibrium towards long run equilibrium with none probability of error. This indicates that deviation from the long-term equilibrium is corrected by $82 \%$ over each year.

Table: 7

Diagnostic tests

\begin{tabular}{|c|c|}
\hline Test Statistics & LM Version \\
\hline A:Serial Correlation & $\operatorname{CHSQ}(1)=20.1198[.00020] \quad \mathrm{F}(1,6)=17.5457[.006]$ \\
\hline B:Functional Form & $\operatorname{CHSQ}(1)=9.1412[.002]$ \\
\hline C:Normality & CHSQ $(2)=1.5256[.466]$ \\
\hline D:Heteroscedasticity & $\operatorname{CHSQ}(1)=1.6196[.203]$ \\
\hline
\end{tabular}

Source: Estimated and tabulated by Authors

Number of diagnostic tests proves no evidence of serial correlation functional form error, Heteroscedasticity and normality effect in the model. 


\section{Conclusions and Policy Recommendations}

The main objective of the study is to investigate the impact of trade openness on gender inequality of Pakistan by applying ARDL approaches for the period 1985 to 2013. Our empirical evidence has shown a negative relation between gender inequality index and trade openness. Government should consider trade openness due to female employment in agriculture and textile sectors. Trade openness will help to reduces gender inequality not only in labour market but also in health and education. As mentioned above, Pakistani trade policymakers assume that international trade is gender neutral, which gives less attention of gender considerations while formulating trade policies. In the comparatively democratic political government of Pakistan, business community, trade associations and large multinational have been considered as main stakeholders in discussion and negotiation of trade policy. Whereas females are mostly unable to connect in full argument on the technical matters related to import and export policies of the country. Changes in trade policy that can influence society at large should take into consideration and aspiration of female's groups.

Capacity building to eliminate unfairness against females in society is crucial and fundamental aspect in the efforts to endorse gender equality in Pakistan. Females are considered beneficiary and victims of trade liberalization both, however, they have lack capability to obtain the benefits from or reduce the harmful shocks of trade policy. There is a need to empowering women in formulating trade policy which is need for sustainable long term economic development in the Pakistan.

These two areas are main part of our export which helps females to take part in economic activities with less skill and abilities. Even foreign direct investment also brings new technologies and knowledge however, it provides more opportunities of job developing country labour due to cheap cost of production and wages. Although there is need to open more technical colleges and institute for enhancement of female labour skills. Most women belong to rural areas of Pakistan where they have no or less facilities of health and education. The women of rural area participate in economic activities to help their male family members. However, the facilities regarding health and education in rural areas are very worse. Few hospital and dispensaries in villages with lack of medical staff and bad hygienic condition and schools with no teachers or less teaching staff are not enough to provide the basic rights to females. Government should make sure the availability of staff in both areas and bring policy for encouraging female enrolment at least secondary level of education. Female employment in agriculture and industry sector has also positive relation with composite gender inequality index. World Development Indicators (2014) illustrated that almost $74 \%$ of female workers in Pakistan are engaged in agriculture. In urban areas over $28 \%$ are connected with textile, wearing clothes and leather industries. Increase in employment will benefit women and it will decrease employment and wage gap if government take step in order to increase the opportunities for women. The effects of trade liberalization on gender inequality are still underexplored aspect in the trade literature especially in case of Pakistan. A reduction in tariff's rates will increase more imports which will encourage to industries in order to update their technology and penetrate the export market. 


\section{References}

Anker, R. (1998). Gender and Jobs: Sex Segregation of Occupations in the World (Geneva: International Labor Organization).

Augusto, L., Saadia, Z. (2005). Women's Empowerment: Measuring the Global Gender Gap, World Economic Forum 2005.

Alexander C. C., Lucky A. L. \& Any M, (2010). The Gender Implications of Trade Liberalization in Southeast Asia, Published by the International Institute for Sustainable Development.

Berik, G. (2002). Mature Export-Led Growth and Gender Wage Inequality in Taiwan, Feminist Economics, vol.6:3.

Chinhui, J. \& Gergely, U. (2013). Trade Liberalization and Gender Inequality, American Economic Review: Papers \& Proceedings 2013, vol.103:3, pp.269-273.

Dickey, D. and Fuller W. (1979). Distribution of the Estimators for Autoregressive Time Series with a Unit Root, Journal of the American Statistical Association, vol.74, pp.427-431.

Hoskyns, C. (2006). Linking Gender and International Trade Policy: Is Interaction Possible? Coventry: Centre for the Study of Globalisation and Regionalisation, University of Warwick.

Hyder. A. \& Jere, R. B. (2011). International Trade Openness and Gender Gaps in Pakistani Labor Force Participation Rates Over 57 Years. PSC Working Paper Series, PSC 11-01. Available online at: http://repository.upenn.edu/psc_working papers $/ 25$

Irene, M., Simonetta, Z. (2012). Trade Policy and Gender Inequalities : A CountryBased Analysis, United Nations Conference on Trade and Development (UNCTAD) ,October, 2012, UNCTAD/WEB/OSG/2012/4.

Joseph, B.A. (2014), Does the Impact of Trade Liberalization on the Informal Sector Have A /gendered Dimension? A Re-examination of the Evidence International Journal of Economics, Commerce and Management United Kingdom, vol.II:10.

Kucera, D. (2001). Foreign Trade of Manufactures and Men and Women's Employment and Earnings in Germany and Japan, International Review of Applied Economics, vol.15:2, pp.129-49. 
Korinek, J. (2005). Trade and Gender: Issues and Interactions. OECD Trade Policy Working Paper No. 24. Paris: OECD.

Matthias, B. \& Sielmann, C. (2006). Gender Inequality and Trade, Review of International Economics, vol.14:3, pp.362-79.

Margawati, A. (2007). A Gender Perspective on the US-Indonesia Free Trade Agreement. In A. C. [23] Chandra H.Kinasih, eds. Checkmate! Indonesia-US Bilateral Free Trade Agreement. Jakarta: IGJ.

McGill, J. (2004). The Different Impacts on Women and Men of Changes in Trade Policies and Rules, http://www.adb.org/Documents/Periodicals/ADB_Review/ 2004/vol36_1/pain_gain.asp.

Mengesha, E. H. (2006). Making the International Trade Regime Work for Gender Equality. Washington, DC: World Bank, http://siteresources.worldbank.org/ INTRAD/Resources/EMengesha.pdf>.

Marchand, M. (1996). Reconceptualizing Gender and Development in an ERA of Globlization, Journal of International Studies, vol.25.

Matthias B., Spielmann, C. (2005). Gender Inequality and Trade, Discussion Paper 308, Hamburgisches Walt-Wirtschafts-Archiv (HWWA).

Naeem, A., Kalim, H.B. (2007). Gender Inequality and Trade Liberalization: A Case Study of Pakistan, Research Report No. 67.

Nordas, H. K. (2003). The Impact of Trade Liberalization on Women's Job Opportunities and Earnings in Developing Countries, World Trade Review, vol.2:2, pp.221-31.

Pradhan, J. P. (2006). How Do Trade, Foreign Investment and Technology Affect Employment Patterns in Organized Indian Manufacturing? Indian Journal of Labour Economics, vol.49:2, pp.249-72.

Pesaran, M. H., and Shin, Y. (1999). An autoregressive distributed lag modelling approach to cointegration analysis. In: Econometrics and Economic Theory in the 20th Century. Cambridge University Press, pp. 371-413.

Pesaran, M. H., Shin, Y and Smith, R. J. (2001). Bounds testing approaches to the analysis of level relationships. J. Appl. Econ. 16:289-326 
Phillips, P.C and Perron, P. (1988). Testing for a Unit Root in Time Series Regression. Biometrika, vol.75:2, pp.335-346.

Rashmi, U. A. (2012). Gender Inequality, Economic Development and Globalization: A State Level Analysis of India, The Journal of Developing Areas, vol.46:1.

Senapaty, M. (2003). Trade, Gender and Employment Issues. In S. Mukhopadhyay \& R. M. Sudarshan, eds. Tracking Gender Equity Under Economic Reforms. Ottawa: International Development Research Center.

Seguino, S. (2000). Gender Inequality and Economic Growth: A Cross-Country Analysis, World Development, Special Issue on Growth, Trade, Finance and Gender Inequality, vol.28:7, pp.1211-1230

Standing,G.(1999), Global Feminization Through Flexible Labor: A Theme Revisited, World Development Vol. 27, No. 3, pp. 583-602, 1999 Elsevier Science Ltd

Siddiqui, Rizwana (2007). Modelling Gender Dimensions of the Impact of Economic Reforms in Pakistan, MPIA Working Paper 2007-13, PEP.

Shireen, A. (2014). Trade Liberalization, Industry Concentration and Female Workers: The Case of Egypt AlAzzawi IZA Journal of Labor Policy 2014, vol.3:20, http://www.izajolp.com/content/3/1/20

Wood, A. (1991). North-South Trade and Female Labor in Manufacturing: An Asymmetry. Journal of Development Studies, vol.27.

Zahra, K. (2008). The Effects of International Trade on Gender Inequality: Women Carpet Weavers of Iran, Working Paper No. 540, http://www.levyinstitute.org/ pubs/wp_540.pdf

Dr. Nooreen Mujaheed is an Assistant Professor in the Department of Economics, University of Karachi.

Azeema Begum is Ph.D Scholar in the Department of Economics, University of Karachi. 